\title{
Software Platform for Analise of Data in The Field of Waste Management
}

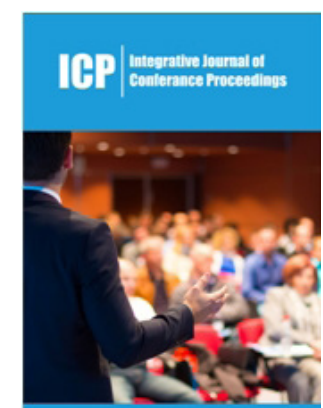

*Corresponding author: Epifancev $\mathrm{K}$, Department of Aerospace Instrumentation, Russia

Submission: 海June 07, 2019

Published: 紫September 06, 2019

Volume 2 - Issue 1

How to cite this article: Epifancev $\mathrm{K}$. Software Platform for Analise of Data in The Field of Waste Management. Int J Conf Proc.2(1). ICP.000525.2019.

Copyright@ Epifancev K, This article is distributed under the terms of the Creative Commons Attribution 4.0 International License, which permits unrestricted use and redistribution provided that the original author and source are credited.
Epifancev $\mathrm{K}^{*}$

Department of Aerospace Instrumentation, Russia

\begin{abstract}
This system will create activity in the waste market, which will involve processors. For this purpose, the research of thermal conductivity of RDF-raw materials of waste landfills in the laboratory of quality control of new functional materials GUAP and programming in Java Script virtual platform ECO 365.The global perspective of the project is the consolidation of the laboratory of new composite materials GUAP to create a waste processing Center with the main focus on research in the field of production and sale of biogas. Demand in the market is large. The used technologies of analytical and measuring instruments and programs of three-dimensional equipment will allow to apply in parallel with the analysis of raw materials the possibility of developing equipment to produce by-products from waste with their subsequent certification. The main goal pursued when working in JavaScript [1,2] is to get closer to a successfully working prototype in the Russian food market the agro 24 platform, which implements the principle of a catalyst for the movement of perishable products. ECO-365 program-analogue in the field of storage, processing and sale of waste [1-3].
\end{abstract}

\section{Materials and Methods}

To manage the system of waste removal and disposal, 4 programs were allocated, working as a full-fledged ERP-system:

A. "RG-soft: waste Removal"-program designed for the analysis and monitoring of waste removal companies, analysis of the threshold of garbage limits, section accounting for waste disposal, As well as: accounting of recyclable materials, Accounting of own coupons, accounting of third-party coupons, Environmental reporting, formation of documents, Accounting of payments from customers. As a drawback-the lack of environmental monitoring of the waste disposal area [3] (Figure 1).

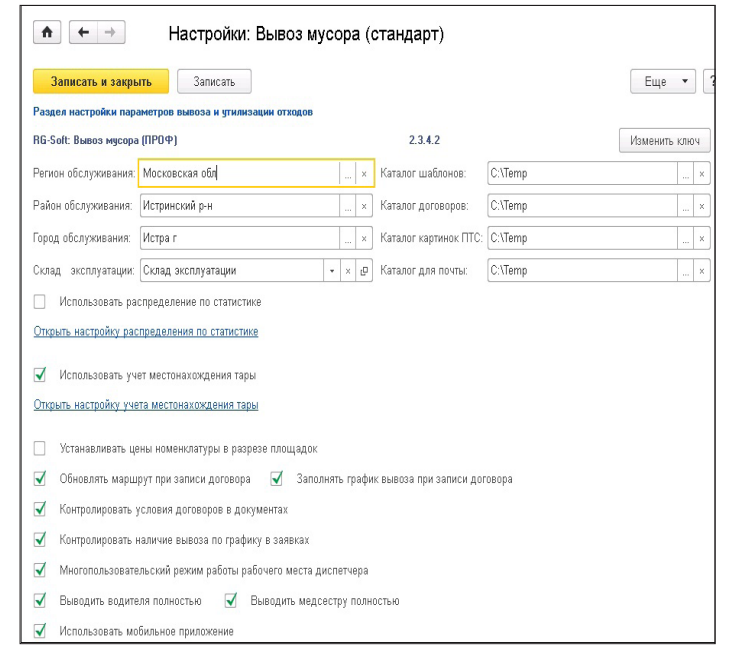

Figure 1: Screenshot of software "RG-Soft».

B. "RG-soft: waste Treatment and disposal "-offers possible forms of waste treatment, but in the absence of the proposed methods at the landfill, as appropriate, which occurs in most cases, does not offer options to sell waste to interested enterprises from other regions. In this case, of course, the carrier has no alternatives other than a simplified waste disposal procedure (Figure 2). 


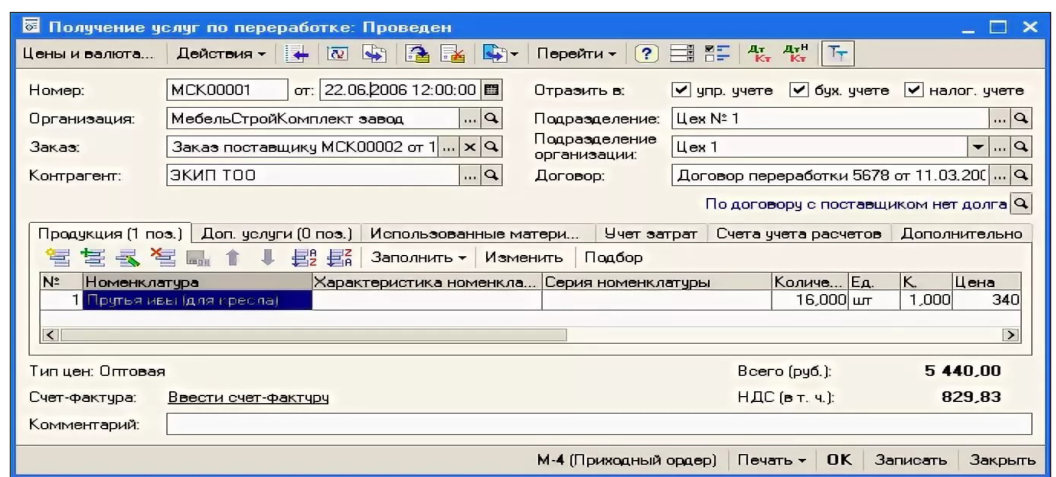

Figure 2: Screenshot of software "1S: Enterprise 8. Waste and recycling management».

C. "Siemens umwelt" - creates the analysis of ecological tension in the course of work of production objects, at the stage of production of finished goods estimates the size of payments to the utilization organizations for placement and processing of waste (Figure 3).

D. "Recycle Map" - with the possibility of pop-up tips on the location of containers for disposal of batteries and incandescent lamps according to the user's geodata [4] (Figure 4).
E. "1S: Enterprise 8. Waste and recycling management" - the configuration supports the main operational processes in the processing plants, such as the reception and shipment of solid waste (MSW) and recyclables, sorting, processing, transportation and disposal of waste. Integration with various equipment used in such enterprises (scales, cameras, access control systems, etc.) is envisaged (Figure 4-7).

F.

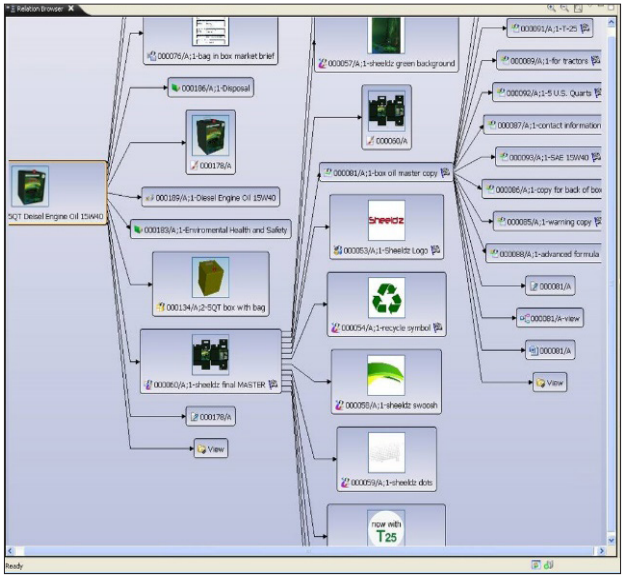

Figure 3: Screenshot of software "Siemens umwelt".

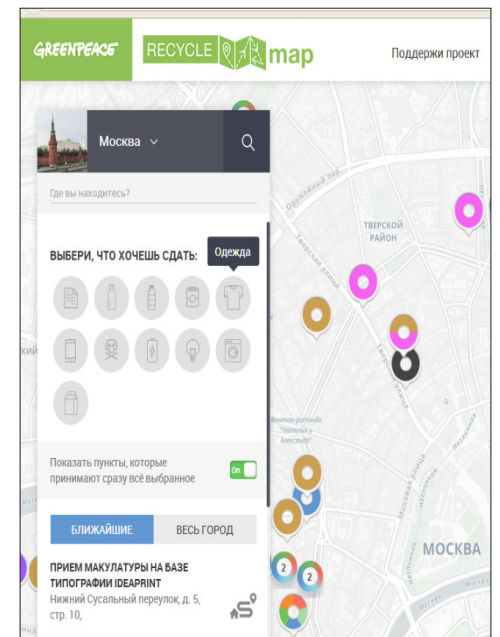

Figure 4: Screenshot of software "Recycle Map». 


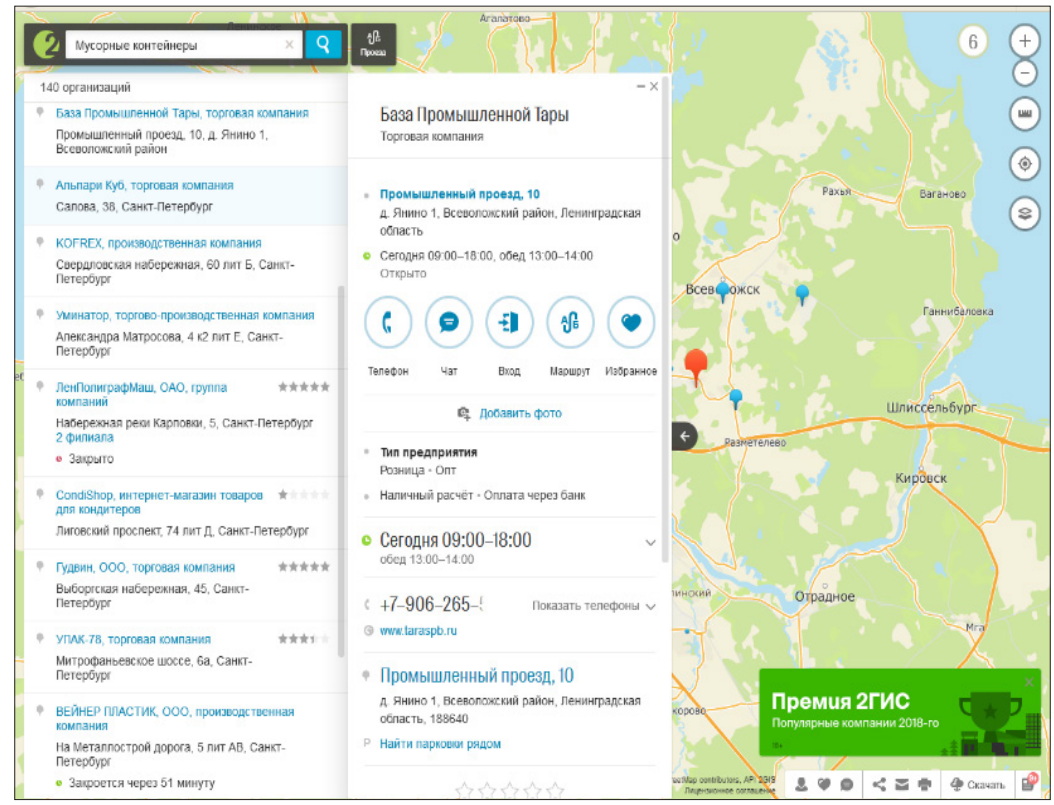

Figure 5: Screenshot of software "2Gis".

\begin{tabular}{|c|c|c|c|c|c|c|c|c|c|}
\hline A & B & Пронсхx & 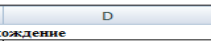 & E & $F$ & $G$ & & $\frac{1}{\text { Krace }}$ & 1 \\
\hline Код по ФКККО & Нанменование вида отходов & \begin{tabular}{c}
\multicolumn{2}{c}{ Пронсес } \\
Пронзводство
\end{tabular} & ормаспне & нанменование & сов соржжан & те, \% масс. & $\begin{array}{l}\text { Арегатнес } \\
\text { состоянне н }\end{array}$ & \begin{tabular}{|l} 
Kласе \\
опасностн
\end{tabular} & Приметанине \\
\hline 31010211294 & 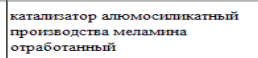 & Произв одство меламина & & & & & 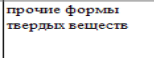 & IV & \\
\hline 31010231614 & 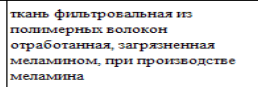 & Произеодспво меламина & & Меламин & & & 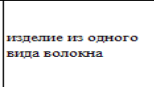 & $\mathrm{rv}$ & 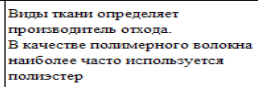 \\
\hline 31070201394 & 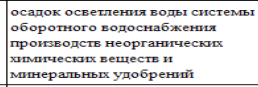 & 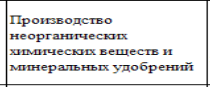 & 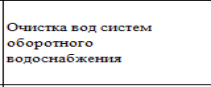 & \begin{tabular}{|l} 
Arкоксид кремндад \\
Bода
\end{tabular} & & & $\mid \begin{array}{l}\text { прочие дистерсныге } \\
\text { системпв }\end{array}$ & $\mathrm{rv}$ & $\begin{array}{l}\text { Может содержать фторидь, } \\
\text { фосфатьт, сульфатьт, кальций }\end{array}$ \\
\hline 31081001333 & 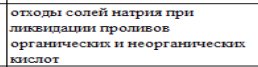 & 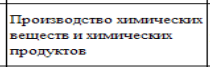 & 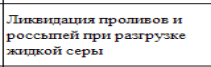 & & & & $\begin{array}{l}\text { IRepдае Е житком } \\
\text { (таста) }\end{array}$ & III & \\
\hline 31086001204 & 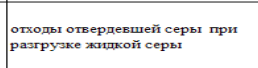 & 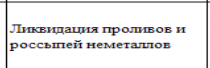 & 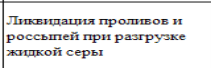 & Cepa & & & твердое & $\mathrm{IV}$ & 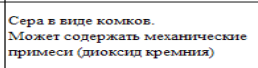 \\
\hline 31211411203 & $\begin{array}{l}\text { отходы бора аморфнного при } \\
\text { прользводстее бора амор фного }\end{array}$ & $\begin{array}{l}\text { Производство бора } \\
\text { aмiмор фного }\end{array}$ & & Eop & & 100 & твердое & III & \\
\hline
\end{tabular}

Figure 6: Main DBRM-library for software "ECO-365".

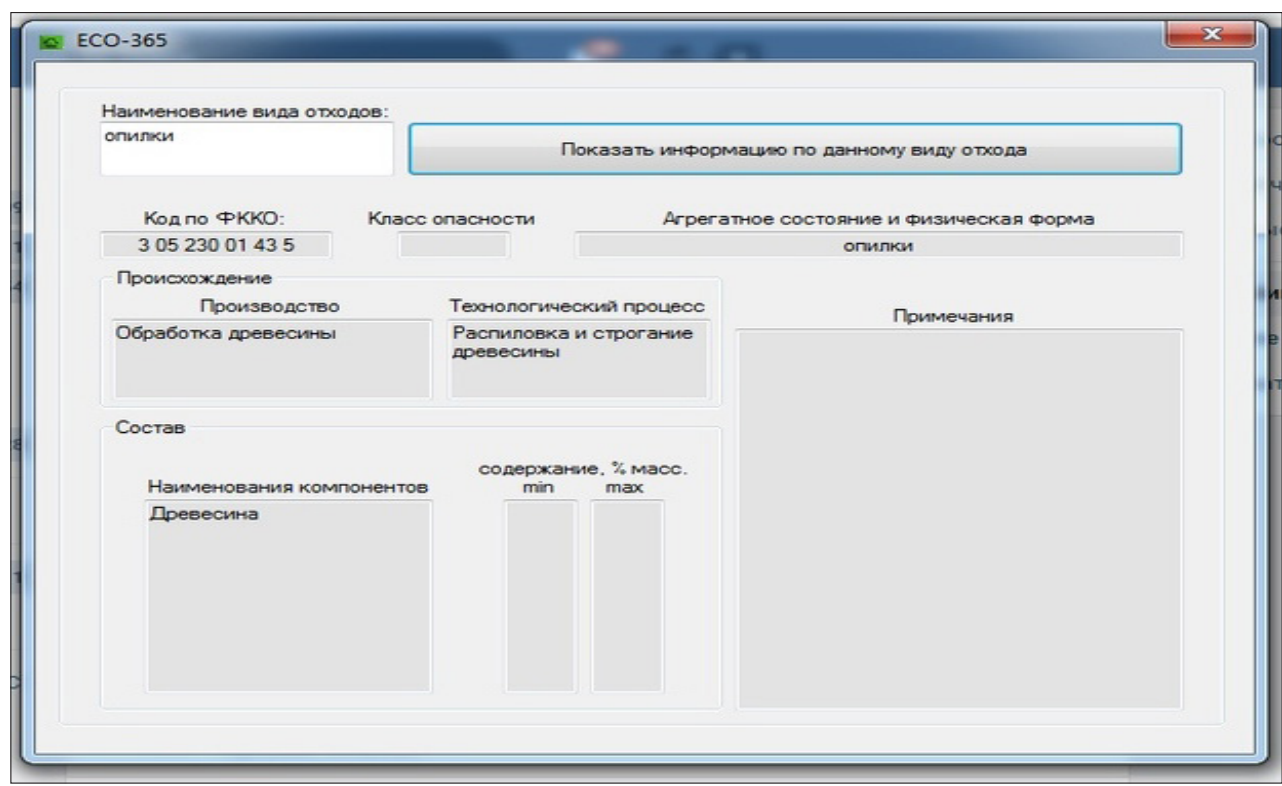

Figure 7: Screenshot of the program window for the assessment and distribution of waste ECO-365, create a match for the sawdust category. 
G. "2GIS" - the program and the application allow the search module to determine the location of the organization receiving the waste closest to the location of the interested person

H. It is possible to conclude that most IT applications are concentrated in the field of construction, engineering, mining industry and economy.

Of course, the main priorities of the Soft program are dispatching; calculation salaries drivers; regulatory accounting of fuel. Accounting for the location of the bunkers; a record of the reception of solid waste and recyclables; accounting of weight and volume characteristics of solid waste and recyclable materials; setting circuits receiving and passing solid waste and recyclables; Accounting for certification and quality control of received and shipped MSW and recyclables; Management of electronic queue at the cash Desk receiving and recyclables; etc. For comparison of the described programs in terms of quality, suitability for waste processing, an appropriate comparison was made in the table (Table 1). Satellite monitoring of City point, however, in our opinion, the program is not aimed at the company's recycling, but only at the disposal of waste, this is its significant drawback, which we seek to finalize in our ECO-365 program. The result of the analysis can be concluded: recycling is a relatively young sphere of industry and therefore, as can be seen from the above programs in this area, there is a software it vacuums. The main principles that were used in the creation of ECO-365: "Federal waste classifier 2017-2018", GOST R 54096-2010 “Resource. Waste treatment”[5,6].

Table 1: Results of research compared programs.

\begin{tabular}{|c|c|c|c|c|c|c|c|c|c|}
\hline & 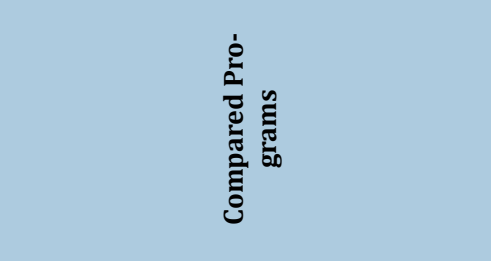 & 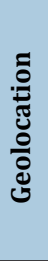 & 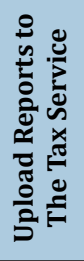 & 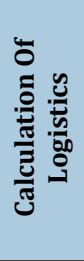 & 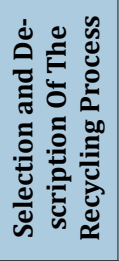 & 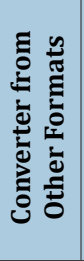 & 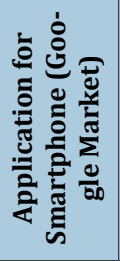 & 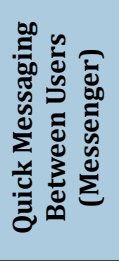 & 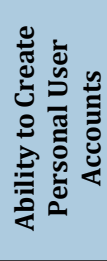 \\
\hline 1 & $\begin{array}{c}\text { RG-SOFT: waste Removal } \\
\text { RG-SOFT: waste Treatment and disposal }\end{array}$ & - & + & + & - & - & - & - & - \\
\hline 2 & $\begin{array}{l}\text { 1S: Enterprise } 8 . \text { Waste and recycling } \\
\text { management }\end{array}$ & - & + & + & - & + & - & - & - \\
\hline 3 & Recycle Map & + & - & + & - & - & + & + & - \\
\hline 4 & Siemens UMWELT & - & + & + & + & + & - & - & - \\
\hline 5 & $2 \mathrm{Gis}$ & + & - & - & - & - & + & + & + \\
\hline
\end{tabular}

\section{Results and Discussion}

The JavaScript language was used as the writing of the application software. JavaScript is an object-oriented language, but the prototyping used in the language causes differences in working with objects compared to traditional class-oriented languages [7-10]. The program constantly monitors these waste databases, which allows you to request a certain type of waste, instantly receive information about the form of its processing and potential processors in your area. In the study of the above programs, actively used for waste disposal in Russia and Europe, it can be concluded that the main rate in the writing and creation of the program is put on logistics, calculation of the cost of disposal, the simplest interface, the choice of landfill. We can say this about all programs equally, in addition to "Siemens umwelt". Indeed, in the "Siemens umwelt" the main task was not the speed of waste disposal and thus the solution of the problem through the clogging of the territory as far as possible from water bodies and residence, but also methods of processing. Siemens proposes to focus on the possibility of profit in the search for recycling technology, which would make it possible not only to get rid of waste, but also profitable to sell them to those who need them. It was from this position that the development began soft "ECO-365".
ECO-365 program-assistant in the field of storage, processing and sale of waste for the operator. The program systematized electronic information resources in the field of waste processing, developed in Java script direct code, adapted to the current requirements of Rosprirodnadzor (Russian ecology department). The method of waste search is maximally adapted in the software interface and visually ergonomic for users. As a writing application software was used Java Script language, which is an object-oriented language. Prototyping used in the language causes differences in working with objects in comparison with traditional class-oriented languages $[11,12]$.

The main fields of the program, which are automatically filled in when specifying any type of waste:

A. FCCO code-11digit classifier code

B. Production-what type of industry waste is generated

C. The process-what the process produces waste

D. Name of components, content, \%wt. - composition of waste

E. Physical state and the physical form-the form in which the waste is transported 
F. Hazard class - to which class I to V the waste relates

G. Note-the content of the additional organic impurities

The program in the form of an application is easily installed on the Windows XP platform and runs provided that the folder is a waste database in Excel format (new data). The database of Rosprirodnadzor, on which the "engine" of the program is based, is the most extensive and is presented in the form of spreadsheets on several sheets. Beginning and ending program text in Java Script is presented below.

\section{using System;}

using System.Collections.Generic;

using System.ComponentModel;

using System.Data;

using System.Drawing;

using System.Linq;

using System.Text;

using System.Windows.Forms;

using System.IO;

using Excel = Microsoft.Office.Interop.Excel;

namespace Waste

\{public partial class MainForm : Form
. Baseline code of "ECO-365"

System.Windows.Forms.Application.DoEvents();

\}

\}

private void MainForm_FormClosed(object sender, FormClosedEventArgs e)

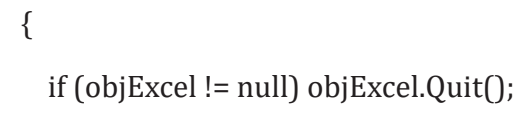

The main requirements for the creation of the program were - the possibility of free installation on a personal computer, the ability to use the system how professional auto directory.

\section{Conclusion}

The program module created based on University laboratories ECO-365 it has been patented (Figure 8 \& 9) and is currently being tested. Currently to admit that this module is only the 1st step in which you want to include and means of geolocation, messaging, opportunity management and creation of the personal account of each user in the environment, with the ability to share videos. It is also expected to broaden the base of the waste, as currently in the standard is not given a detailed description of possible recycling of each waste individually, are not defined a particular company or polygons for mechanical recycling, which havr in the narrow direction of the recycling of a certain list of materials.

\{

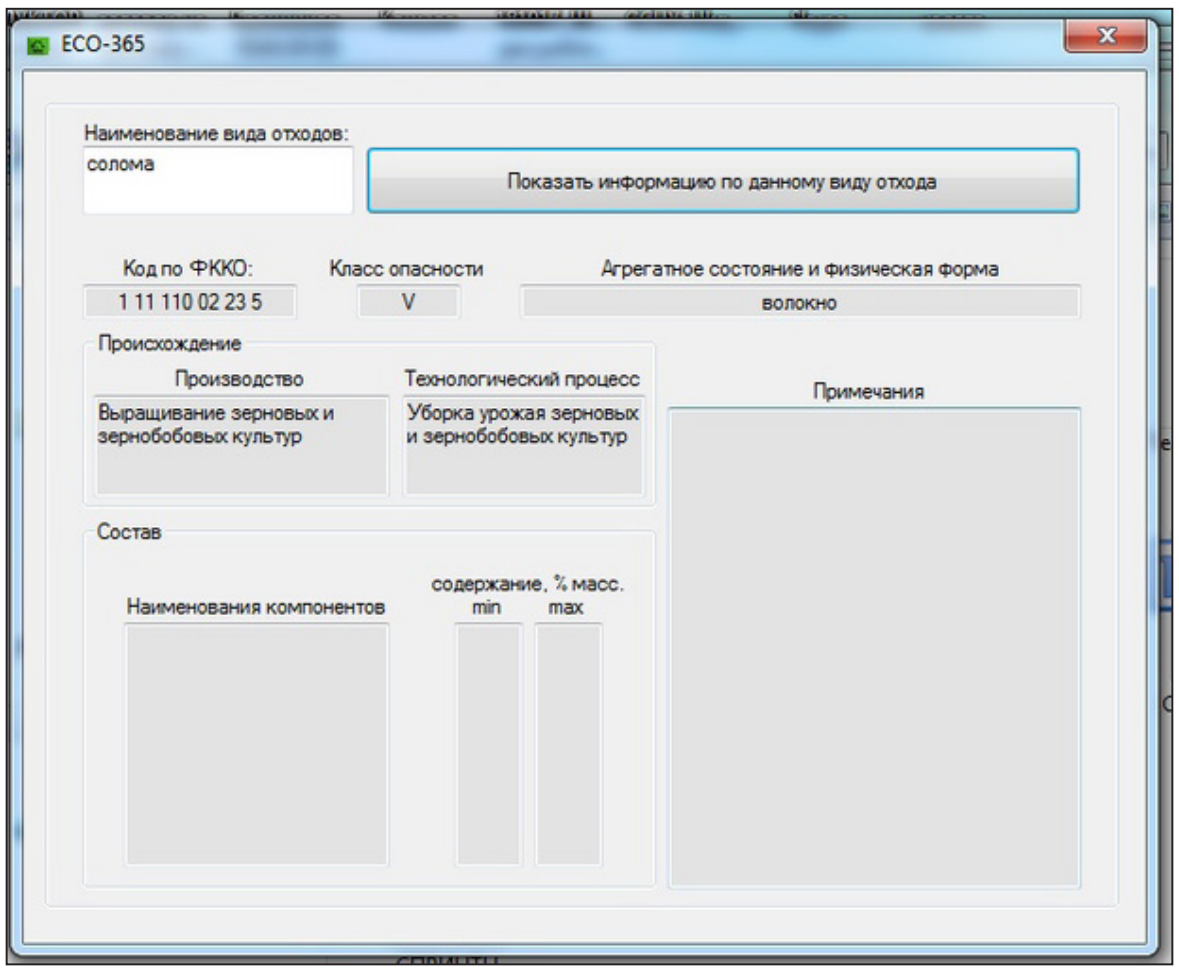

Figure 8: Screenshot window for evaluation, and placement of waste ECO-365 create a straw category match". 


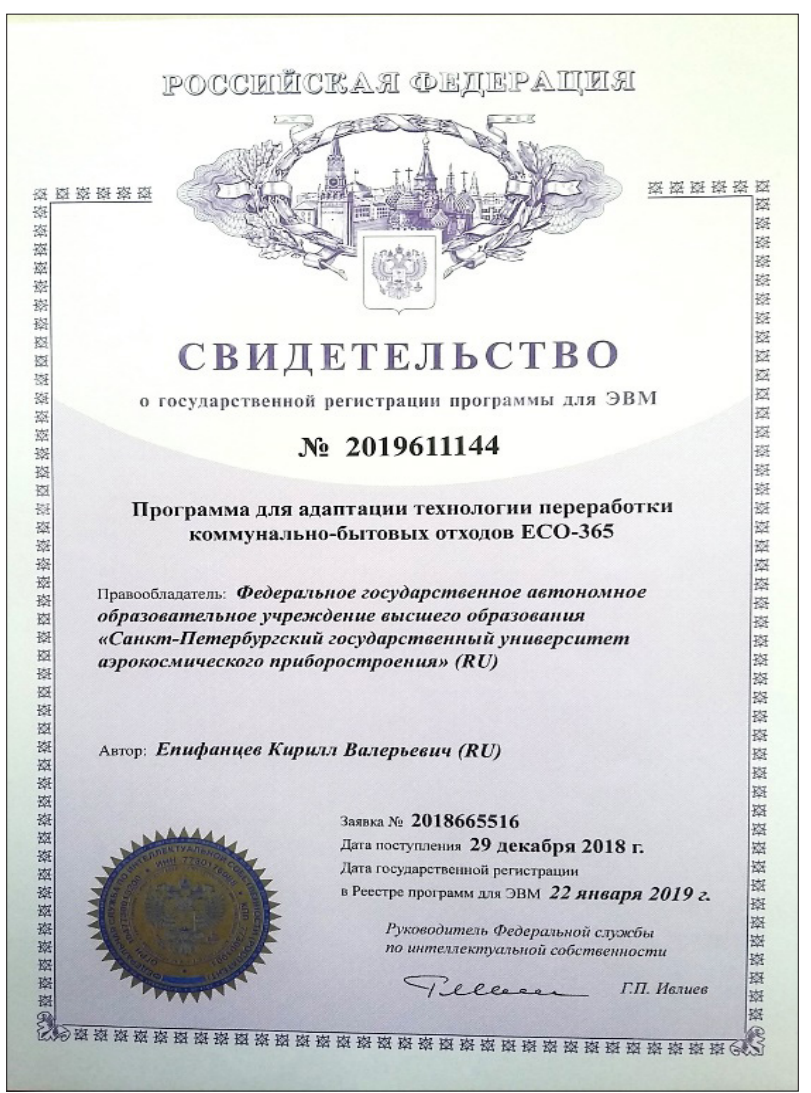

Figure 9: Acquire an inventor's certificate for ECO-365.

\section{References}

1. Lindenau NI (1977) Origin, prevention, and suppression of spontaneous fires in coal mines. In: Maevskaya VM, Krylov VF (Eds.), M: Nedra, p. 387.

2. Yinlin J, Ting R, Peter W (2016) Comparative study of dust control practices in Chinese and Australian longwall coal mines. International Journal of Mining Science and Technology 26(2): 199-208.

3. Furman E (2005) Measurement of thermal conductivity on it- $\lambda-400$ educational-electronic text edition prepared at the department of foundry and hardening technology, Russia, p. 10.

4. Functional (2013) Introducing functional programming with underscore. In: Michael Fogus (Ed.), Moscow, Russia, p. 260.

5. Federal waste classifier (2018) Rosprerodandajar, pp. 10-16.

6. GOSTR (2010) Resource. Waste treatment, pp. 1-6.

7. Mineral Resources (2009) Government Printing Office, Washington, USA 1: 767.
8. European Standard EN (1991) Determination of conventions on a fraction part for suspended solids measurement in the workplace. German version, pp. 2-8.

9. Epifancev K, Nikulin A, Kovshov S, Mozer I, Brigadnov I (2013) Modeling of peat mass process formation based on 3D analysis of the screw machine by the code YADE. American Journal of Mechanical Engineering 1(3): 73-75.

10. Epifancev K (2018) Modernization instruments for technical diagnostics machines. Adv in Civil Engin \& Technol 1(2): 1.

11. K Epifancev, T Mishura (2018) Research defects of fatigue failures of screws in solid works instrumentation. Open Access Journal of Science 2(3): 208-210.

12. High Performance (2010) Reilly. In: Zakas NC (Ed.), Moscow, Russia, p. 232. 